\title{
Comment
}

Neuroepidemiology 2011;36:148-149

DOI: $10.1159 / 000325368$

\section{Are the Prevalence and Incidence of Multiple Sclerosis Changing?}

\author{
Julián Benito-León ${ }^{\mathrm{a}-\mathrm{c}}$ \\ aDepartment of Neurology, University Hospital '12 de \\ Octubre', b Centro de Investigación Biomédica en Red \\ sobre Enfermedades Neurodegenerativas (CIBERNED) and \\ 'Department of Medicine, Faculty of Medicine, \\ Complutense University, Madrid, Spain
}

Multiple sclerosis (MS) is one of the most common causes of disability among young people $[1,2]$. An outright cure for the disease still remains elusive, leaving both patients and their caregivers with the challenge of living with a chronic medical condition that affects their health-related quality of life [3-11]. It is therefore imperative to focus research efforts on the search for the etiology of this disease and, hence, epidemiological studies are essential.

The epidemiology of MS has always been fascinating. Yet data over recent years have challenged the traditional view that there is a north-to-south gradient in the occurrence of this disease in the northern hemisphere and a south-to-north gradient in the southern hemisphere, with MS being much less common in people living near the equator [1]. An increase in the prevalence and incidence of this disease has been observed in Europe, the Mediterranean Basin and, possibly, worldwide $[1,12]$. In the present issue of Neuroepidemiology, Elhami et al. [13] have reinforced this message. These authors examined the 20-year incidence trend and point prevalence of MS in Tehran Province, Iran. Data on patients with a diagnosis of definite MS were obtained from the Iranian MS Society. The most interesting observations were that the age- and sex-adjusted incidence rates increased significantly from $0.68 / 100,000$ (1989) to a peak of 5.68/100,000 (years 2005 and 2006), reflecting an 8.3-fold rise during that period. Further, the age-adjusted prevalence was 50.57/100,000 (females: 77.24 and males: 25.54) [13]. The results of this study are of special interest. Aside from the fact that no other incidence studies of MS have been conducted in Tehran, the results suggest that this geographical region is currently a high-risk area for MS, since the incidence has increased markedly over the last 20 years [13].

The study had several strengths, including the large sample size, the design and the well thought-out approach to the statistical analyses. The study was not without limitations. As noted by the authors, data from participants who were not ascertained by the Iranian MS Society were lacking. The authors were aware of the limitation but indicated that this limitation did not interfere with the assessment of trend data, which was the main object of this survey.

Leaving aside issues of strengths and limitations, the study again demonstrates that prevalence and incidence of MS have been increasing in recent decades. However, the question is whether this increase in worldwide prevalence is real. There are currently some doubts. The increased availability of magnetic resonance imaging and, therefore, improved detection of MS may explain a perceived increase in incidence rates [14]. Likewise, the increase in prevalence may be due to an improved probability of survival [15]. Indeed, the increase in prevalence and incidence of this disease is not a universal fact. For instance, in the population of Olmsted County, Minn., USA, whose registry depends on the Mayo Clinic, the prevalence and incidence rates of MS appear to have been stable rather than increasing over the past 20 years, after age and gender adjustment to a common population. By contrast, very detailed studies suggest that this increase is real, particularly in females $[16,17]$.

The question is why this increase may be occurring. The etiology of MS is complex and likely involves multiple genes and their interactions with environmental factors. Although an increasing body of evidence suggests that this disease is mediated by an autoimmune reaction among susceptible people to a widespread pathogen (Epstein-Barr virus? Candida species?) $[18,19]$ that is ubiquitous in the developed world, none of the current hypotheses on the etiology of MS are completely convincing [12]. Vitamin D production in the skin during sun exposure may potentially explain the increased prevalence of MS at higher latitudes, but this does not explain the overall increase in incidence [20]. The hygiene hypothesis has also generated a large number of studies [21]. What seems clear is that recent reports suggest that the latitude gradient could be disappearing and that the female-to-male ratio among patients with MS has increased in the past decades [22].

In the search for the cause of MS, epidemiology is essential. Valuable clues to the etiology may be derived from the epidemiological features of the disease, and the subsequent search for risk factors in analytical studies. Knowledge of the epidemiology of MS is therefore necessary in creating etiological hypotheses, since only hypotheses consistent with the epidemiological profile deserve careful testing.

Acknowledgement

J. Benito-León is supported by NIH R01 NS039422 from the National Institutes of Health, Bethesda, Md., USA.

\section{KARGER}

두 2011 S. Karger AG, Basel

Fax +41613061234 E-Mail karger@karger.ch www.karger.com 


\section{References}

1 Pugliatti M, Sotgiu S, Rosati G: The worldwide prevalence of multiple sclerosis. Clin Neurol Neurosurg 2002;104:182-191.

-2 Benito-León J, Martin E, Vela L, Villar ME, Felgueroso B, Marrero C, Guerrero A, Ruiz-Galiana J: Multiple sclerosis in Móstoles, central Spain. Acta Neurol Scand 1998;98:238-242.

3 Benito-León J, Morales JM, Rivera-Navarro J: Health-related quality of life and its relationship to cognitive and emotional functioning in multiple sclerosis patients. Eur J Neurol 2002;9:497-502.

4 Benito-León J, Martínez-Martín P: Health-related quality of life in multiple sclerosis. Neurologia 2003;18:210-217.

5 Benito-León J, Morales JM, Rivera-Navarro J, Mitchell A: A review about the impact of multiple sclerosis on health-related quality of life. Disabil Rehabil 2003;25:1291-1303.

-6 Morales-González JM, Benito-León J, Rivera-Navarro J, Mitchell AJ, GEDMA Study Group: A systematic approach to analyse health-related quality of life in multiple sclerosis: the GEDMA study. Mult Scler 2004 $10: 47-54$.

7 Mitchell AJ, Benito-León J, González JM, Rivera-Navarro J: Quality of life and its assessment in multiple sclerosis: integrating physical and psychological components of wellbeing. Lancet Neurol 2005;4:556566

8 Rivera-Navarro J, Morales JM, Benito-León J: Informal caregiving in multiple sclerosis patients: data from the Madrid demyelinating disease group study. Disabil Rehabil 2003;25:1057-1064.

-9 Rivera-Navarro J, Morales-González JM, Benito-León J, Mitchell AJ The social and familial dimensions: experiences of caregivers and people with multiple sclerosis. The Gedma Study. Rev Neurol 2008;47:281285.

10 Rivera-Navarro J, Benito-León J, Oreja-Guevara C, Pardo J, Dib WB Orts E, Belló M, Caregiver Quality of Life in Multiple Sclerosis (CAREQOL-MS) Study Group: Burden and health-related quality of life of Spanish caregivers of persons with multiple sclerosis. Mult Scler 2009;15:1347-1355.

11 Benito-León J, Rivera-Navarro J, Guerrero AL, de Las Heras V, Balseiro J, Rodríguez E, Belló M, Martínez-Martín P, Caregiver Quality of Life in Multiple Sclerosis (CAREQOL-MS) Study Group: The CAREQOLMS was a useful instrument to measure caregiver quality of life in multiple sclerosis. J Clin Epidemiol 2010, E-pub ahead of print

12 Benito-León J, Bermejo-Pareja F: Is the epidemiology of multiple sclerosis changing? Rev Neurol 2010;51:385-386.
13 Elhami S-R, Mohammad K, Sahraian MA, Eftekhar H: A 20-year incidence trend (1989-2008) and point prevalence (March 20,2009) of multiple sclerosis in Tehran, Iran: a population-based study. Neuroepidemiology 2011;36:141-147.

14 Sarasoja T, Wikstrom J, Paltamaa J, Hakama M, Sumelahti ML: Occurrence of multiple sclerosis in central Finland: a regional and temporal comparison during 30 years. Acta Neurol Scand 2004;110:331-336.

15 Brønnum-Hansen H, Koch-Henriksen N, Stenager E: Trends in survival and cause of death in Danish patients with multiple sclerosis. Brain 2004; 127:844-850.

16 Hirst C, Ingram G, Pickersgill T, Swingler R, Compston DA, Robertson NP: Increasing prevalence and incidence of multiple sclerosis in South East Wales. J Neurol Neurosurg Psychiatry 2009;80:386-391.

17 Barnett MH, Williams DB, Day S, Macaskill P, McLeod JG: Progressive increase in incidence and prevalence of multiple sclerosis in Newcastle, Australia: a 35-year study. J Neurol Sci 2003;213:1-6.

18 Ascherio A, Munger KL: 99th Dahlem conference on infection, inflammation and chronic inflammatory disorders: Epstein-Barr virus and multiple sclerosis - epidemiological evidence. Clin Exp Immunol 2010; 160:120-124

19 Benito-León J, Pisa D, Alonso R, Calleja P, Díaz-Sánchez M, Carrasco L: Association between multiple sclerosis and Candida species: evidence from a case-control study. Eur J Clin Microbiol Infect Dis 2010; 29:1139-1145.

20 Pierrot-Deseilligny C, Souberbielle JC: Is hypovitaminosis D one of the environmental risk factors for multiple sclerosis? Brain 2010;133:18691888 .

21 Fleming JO, Cook TD: Multiple sclerosis and the hygiene hypothesis. Neurology 2006;67:2085-2086.

22 Alonso A, Hernán MA: Temporal trends in the incidence of multiple sclerosis: a systematic review. Neurology 2008;71:129-135.

Dr. Julián Benito-León

Department of Neurology, University Hospital 12 de Octubre

Av. de Córdoba, s/n

ES-28041 Madrid (Spain)

Tel. +34 91390 8600, E-Mail jbenitol@meditex.es 